\title{
Conformity Assessment in the Public Procurement of Accessible ICT
}

\author{
Stephan Corvers , Loic Martínez-Normand, Clas Thorén . Enrique Varela , \\ Eric Velleman, and Klaus-Peter Wegge \\ Corvers Procurement Services BV, 's Hertogenbosch, Netherlands \\ DLSIIS, Facultad de Informática, Universidad Politécnica de Madrid, Spain \\ Clas Thorén Consulting. Ekerö, Sweden \\ Fundación ONCE and freelance consultant, Madrid. Spain \\ Bartiméus Accessibility Foundation, Utrecht, Netherlands \\ Siemens Accessibility Competence Center, Paderborn. Germany \\ s.corversacorvers.com, loicefi.upm.es, clas.thoren@gmail.com. \\ evarelacogmail.com, e.vellemanebartimeus.nl, weggegc-lab.de
}

\begin{abstract}
Public procurement is an important instrument for improving the accessibility of the information society. In Europe, in December 2005, the European Commission issued mandate M/376 to CEN. CENELEC and ETSI, to harmonize and facilitate the public procurement of accessible ICT products and services by identifying a set of functional European accessibility requirements for public procurement of products and services in the ICT domain. The mandate is to be carried out in two phases: Phase I - inventory of accessibility requirements and assessment of suitable testing and conformity schemes. and Phase II - standardization activities. This paper presents an overview of the technical report produced by the authors as members of a CEN and CENELEC project team assigned to carry out "an analysis of testing and conformity schemes of products and services meeting accessibility requirements". The work was developed from October 2007 until October 2008.
\end{abstract}

\section{Introduction}

In Europe, USA, Canada, Australia, Japan and many other countries public procurement is regarded as an important instrument for improving the accessibility of the information society.

In December 2005 the European Commission issued a mandate M/376 [1] to CEN, CENELEC and ETSI. One key objective of this mandate was to harmonize and facilitate the public procurement of accessible products and services in the field of information and communication technologies (ICT) by identifying a set of functional European accessibility requirements.

A crucial element of public procurement processes is to verify that the products offered in the tenders fulfill the requirements set out in the call-for-tender. In particular, the procurer has to be confident that the statements on conformity claimed by the awarded supplier are true. Preferably, such statements should be the result of a conformity assessment process compliant to international standards. 
By conformity assessment is meant a demonstration that a product (in a general sense) fulfils specified requirements [5]. In most cases this demonstration is carried out either by the manufacturer of the product (called "first party" in the conformity assessment field) or an independent third party organization.

A conformity assessment system is a set of rules, procedures and management for carrying out conformity assessment. A conformity assessment scheme is a conformity assessment system related to specified objects to which the same specified requirements, rules and procedures apply. This means that a conformity assessment scheme is the application of a conformity assessment system to a specific situation in which the type of objects (products) and the requirements are always the same.

Mandate M/376 is to be carried out in two phases: Phase I - Inventory of European and international accessibility requirements and assessment of suitable testing and conformity schemes, and Phase II - Standardization activities.

This paper presents an overview of the technical report produced by the authors as members of a CEN and CENELEC project team assigned to carry out "an analysis of testing and conformity schemes of products and services meeting accessibility requirements". The work was developed from October 2007 until October 2008 and can be found in the complete report [2]. Another report focused on functional accessibility requirements, standards, and the current state of public procurement of accessible ICT was produced by ETSI specialist task force 333 [3].

\section{Approach}

The approach taken by our team consisted of the following six steps:

1. Search for existing schemes in the field of ICT product accessibility.

2. Search for systems or schemes in other domains that could be applicable to the accessibility of ICT products.

3. Define a model to analyze the difterent properties of a conformity assessment system or scheme, the "dimensions".

4. Apply this model to describe the conformity assessment systems and schemes that have been found in steps 1 and 2 .

5. Define a model to analyze the properties of a public procurement context, the "criteria". They are means for determination of the type of conformity assessment scheme that best fits each procurement situation.

6. Apply this model of public procurement analysis to describe a small set of scenarios. The details of the influence of the public procurement context criteria on the dimensions of conformity assessment schemes are confined to these scenarios.

The dimensions and criteria together make up a multi-criteria decision support system, aimed at assisting the procurer to find the conformity assessment system or scheme that best fits the procurement in question.

The rest of this paper will present the main results of our research. Section 3 will describe the dimensions to analyze conformity assessment systems and schemes. Section 4 will summarize information of existing conformity assessment systems and schemes, using the dimensions of section 3 . Then, section 5 will describe the criteria used to analyze the properties of a public procurement context, and section 6 will 
present an overview of the scenarios that were defined in the complete report. Finally, section 7 will present some conclusions and indications of future work.

\section{The Dimensions}

The initial goal of the analysis of conformity assessment systems and schemes for public procurement of accessible ICT products was to generate a matrix similar to the one presented in the IDC report [4]. That report presents a table of criteria for consideration in evaluating and making an informed decision about a conformity assessment approach appropriate for the circumstances.

The IDC report applied several criteria to only two types of conformity assessment: mandatory third-party certification vs. voluntary self- declaration of conformity. This was considered to be a limited approach given the diversity of conformity assessment systems that can be applied. For instance, a distinction has to be made between the involved parties (first, third) and whether the assessment is mandatory or voluntary.

After an in-depth study of the components of conformity assessment systems and schemes, the project team decided to further decompose conformity assessment systems into several dimensions. This decomposition was made based on the functional approach to conformity assessments defined by EN ISO/IEC 17000 [5], which is comprised of four functions (Figure 1).

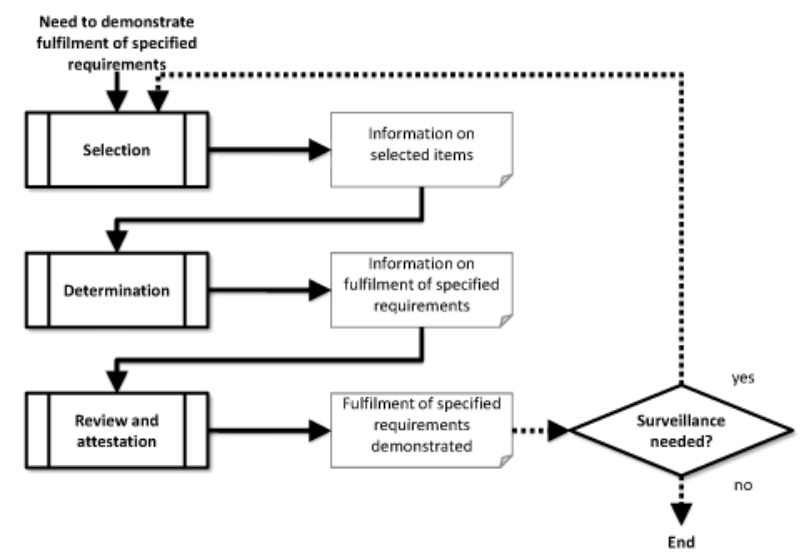

Fig. 1. The functional model of conformity assessment (EN ISO/IEC 17000:2004)

The first function is selection: it involves planning and preparing activities in order to collect or produce all the information and input needed for the subsequent determination function. Such activities may concern the object of assessment (e.g. whether sampling is needed), the specified requirements (are all requirements applicable?) and the methods of determination (e.g. inspection or testing). The second function is determination: it includes the evaluation activities that are undertaken to develop complete information regarding fulfillment of the specified requirements by the object of conformity assessment or its sample. The third function is review and attestation. 
Review is the final stage of checking before taking the important decision as to whether or not the object of conformity assessment has been reliably demonstrated to fulfill the specified requirements. Attestation is the conformity statement, usually presented in a form that most readily reaches all of the potential users. The fourth function is surveillance. Conformity assessment can end when attestation is performed. In some cases, however, the assessment functions may need to be systematically iterated to maintain the validity of the statements.

Table 1 provides an overview of the dimensions identified in our work, with a short description of each of them. Full detail can be found in the complete report [2].

Table 1. The dimensions defined to describe conformity assessment systems and schemes

\begin{tabular}{|c|c|}
\hline \multicolumn{2}{|l|}{ Selection } \\
\hline $\begin{array}{l}\text { Type of } \\
\text { requirements (TR) }\end{array}$ & $\begin{array}{l}\text { The type of requirements that will be used in the assessment. The requirements } \\
\text { can be based on international standards, on European standards, on national } \\
\text { standards, on de facto standards or on other sources. For the definition of stan- } \\
\text { dard, see annex VI of the Directive 2004/18/EC [6]. }\end{array}$ \\
\hline Scalability (SC) & $\begin{array}{l}\text { Whether the conformity assessment scheme is scalable. Scalability is a capability } \\
\text { of a scheme to enable its application to products of varying degrees of complex- } \\
\text { ity. Scalability depends on the selection of the object of assessment (or parts or } \\
\text { functions of it) and on the selection of the determination methods to be used. A } \\
\text { scalable scheme can be applied equally well to simple and complex products. }\end{array}$ \\
\hline \multicolumn{2}{|r|}{ 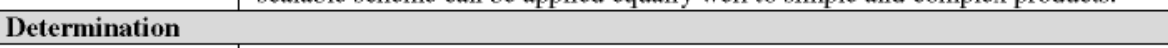 } \\
\hline $\begin{array}{l}\text { Method of } \\
\text { determination } \\
\text { (MD) }\end{array}$ & $\begin{array}{l}\text { The method that is used to determine the resulting value for each requirement. } \\
\text { Some types of determination activities defined in EN ISO/IEC 17000:2004 are } \\
\text { testing, inspection, audit and peer assessment. The value of this dimension can be } \\
\text { "mixed" if several determination methods can be used in one system or scheme. }\end{array}$ \\
\hline External (EX) & $\begin{array}{l}\text { Whether the determination activities are done by the same organization that will } \\
\text { provide the attestation (external=no) or by an external entity (like a laboratory) } \\
\text { that is contracted by the organization providing the attestation (external=yes). }\end{array}$ \\
\hline Type of party (TP) & $\begin{array}{l}\text { Type of party doing the determination. It can be: a first party: (the person or } \\
\text { organization that provides the object), a second party: (person or organization that } \\
\text { has a user interest in the object, like purchasers, users of products, potential } \\
\text { customers...) and a third party: (person or body that is independent of the person } \\
\text { or organization that provides the object and of user interests in that object). For } \\
\text { third parties, their independence will be measured using the types identified in } \\
\text { EN ISO/IEC 17020, from type A (fully independent) to type C (not independent). }\end{array}$ \\
\hline \multicolumn{2}{|c|}{ Review and Attestation } \\
\hline Type of party (TP) & Type of party responsible for the attestation. Same values as above. \\
\hline $\begin{array}{l}\text { Detail of } \\
\text { attestation (DA) }\end{array}$ & $\begin{array}{l}\text { This dimension represents the level of detail of the attestation that is generated as } \\
\text { a result of the conformity assessment process. }\end{array}$ \\
\hline Publicity (PU) & $\begin{array}{l}\text { This dimension indicates whether the resulting attestation is made publicly avail- } \\
\text { able to external bodies (such as, for example, the public procurers or users). }\end{array}$ \\
\hline \multicolumn{2}{|l|}{ Surveillance } \\
\hline Existence (ES) & $\begin{array}{l}\text { This dimension indicates whether or not the conformity assessment scheme } \\
\text { includes surveillance. }\end{array}$ \\
\hline $\begin{array}{l}\text { Complaint system } \\
\text { (CS) }\end{array}$ & $\begin{array}{l}\text { This indicates whether the conformity assessment scheme includes a complaint } \\
\text { system that is maintained by the customer (the contracting authority), by the } \\
\text { provider of the attestation or by a mediation party (like a disability rights office). }\end{array}$ \\
\hline \multicolumn{2}{|l|}{ Other } \\
\hline Mandatory (MA) & $\begin{array}{l}\text { This dimension indicates whether or not the conformity assessment scheme is } \\
\text { mandatory. Mandatory systems are the ones regulated by national laws. }\end{array}$ \\
\hline
\end{tabular}




\section{Existing Conformity Assessment Systems and Schemes}

During the preparation of the full report, several conformity assessment systems and schemes were found. These were divided into three groups: general systems as described by standards, existing schemes for ICT accessibility and, finally, systems or schemes outside the ICT domain that could be of interest.

\subsection{General Conformity Assessment Systems}

The first group contains conformity assessment systems as defined by international and European standards and, in addition, a generic methodology for conformity assessment of the accessibility of web sites. The systems described in this group are: generic first party assessment (as defined in ISO/IEC 17000:2004), Supplier's declaration of conformity (EN ISO/IEC 17050-1:2004), generic second party assessment (as defined in ISO/IEC 17000:2004), generic third party assessment (as defined in ISO/IEC 17000:2004), inspection (EN ISO/IEC 17020:1998), product certification (EN 4501 1:1998) and, finally, UWEM [7].

As the listed systems are generic, most of the dimensions don't have defined values and the main differences are on the type of parties doing the assessment and the details of the attestations. Detailed information can be found in the full report [2].

\subsection{Existing Schemes Specific to ICT Accessibility}

The second group is based on the research carried out to find and describe existing conformity assessment schemes in the field of ICT accessibility. Several examples were found, and they were grouped into categories, depending of the type of product, the type of party, mandatory and public funding. Each category has a key example, although most of the categories contain several examples. Table 2 summarizes the values assigned for each dimension in the scheme categories:

1. Web sites. Centification by accredited type A third party (WCERT). In Spain there is one official accessibility certification of websites, offered by AENOR and conforming to EN 45011:1998 and ISO/IEC Guide 65.

2. Web sites. Inspection by accredited type A third party (WINSP). In the Netherlands there are two examples of inspection performed by accredited type A third parties (conforming to ISO/IEC 17020): Foundation Quality Mark "drempelvrij.nl" and the Accessibility Foundation. Both use UWEM as a conformity assessment system.

3. Web sites. Publicly-funded assessment (WPUBL). In Germany there is one project, BIK (Barrierefrei Informieren und Kommunizieren), funded by the German Federal Ministry of Labour and social affairs, that defines a complete test to evaluate conformity with the Amendment BITV of the German equal opportunities act (based on WCAG 1,0).

4. Web sites. Assessment by type $C$ third party (WCTHRD). This is the most common example: a conformity assessment scheme offered by an organization that is not fully independent. The one described in the report is offered by Segala.

5. Web sites. Mutual recognition between European parties (WMUT). Euracert is a unique example of mutual recognition between conformity assessment bodies. It is 
Table 2. Values assigned for each dimension in existing schemes specific to ICT accessibility

\begin{tabular}{|c|c|c|c|c|c|c|c|c|c|}
\hline \multirow{2}{*}{\multicolumn{10}{|c|}{ 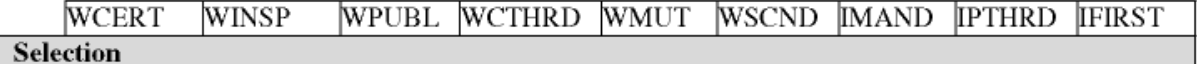 }} \\
\hline & & & & & & & & & \\
\hline TR & $\begin{array}{l}\text { National } \\
\text { Std. }\end{array}$ & De facto & $\begin{array}{l}\text { National } \\
\text { legislat. }\end{array}$ & $\begin{array}{l}\text { Variable } \\
\text { (de facto, } \\
\text { legislation) }\end{array}$ & $\begin{array}{l}\text { De } \\
\text { facto }\end{array}$ & Other & $\begin{array}{l}\text { National } \\
\text { legislat. }\end{array}$ & \begin{tabular}{|l} 
Internat. \\
Std.
\end{tabular} & $\begin{array}{l}\text { National } \\
\text { legislat. }\end{array}$ \\
\hline $\mathrm{SC}$ & Yes & Yes & Yes & Yes & Yes & Yes & No & No & - \\
\hline \multicolumn{10}{|c|}{ Determination } \\
\hline $\mathrm{MD}$ & $\begin{array}{l}\text { Inspection } \\
\& \text { audit }\end{array}$ & Inspection & Mixed & Mixed & Mixed & Mixed & Mixed & Testing & Mixed \\
\hline EX & Yes & No & No & No & No & No & No & Yes & - \\
\hline TP & $3^{\text {rd }}(\mathrm{C})$ & - & - & - & - & - & - & $3^{\text {rd }}(\mathrm{A})$ & - \\
\hline \multicolumn{10}{|c|}{ Review and Attestation } \\
\hline TP & $\begin{array}{l}\text { Accred. } \\
3^{\text {rd }}(\mathrm{A})\end{array}$ & $\begin{array}{l}\text { Accred. } \\
3^{\text {rd }}(\mathrm{A})\end{array}$ & $\begin{array}{l}\text { Accred. } \\
3^{\text {rd }}(\mathrm{A})\end{array}$ & $3^{\text {rd }}(\mathrm{B})$ & $3^{\text {rd }}(\mathrm{C})$ & Second & $3^{\text {rd }}(\mathrm{A})$ & $3^{\text {rd }}(\mathrm{A})$ & First \\
\hline DA & No & No & Detailed & $\begin{array}{l}\text { Detailed } \\
\text { (machine) }\end{array}$ & Detailed & Detailed & Detailed & Detailed & Detailed \\
\hline PU & Yes & Yes & Yes & Yes & Yes & Yes & Yes & Yes & Yes \\
\hline \multicolumn{10}{|c|}{ Surveillance } \\
\hline ES & Yes & Yes & No & Yes & Yes & No & - & Yes & No \\
\hline SC & Yes & Yes & No & Yes & Yes & No & - & - & Supplier \\
\hline \multicolumn{10}{|c|}{ Other } \\
\hline MA & No & No & No & No & No & No & Yes & No & No \\
\hline
\end{tabular}

an agreement between three private organizations: AnySurfer in Belgium, Accessiweb in France and Technosite in Spain. They share the same requirements (WCAG 1.0) and the same method for accessibility evaluation (UWEM)).

6. Web sites. Assessment by second party (WSCND). There is only one example in this category: the See it Right audit. It is a service provided by the RNIB in the UK. As RNIB is an organization representing blind and visually impaired users, it can be considered to be a second party: it is an organization that has a user interest in the object of assessment.

7. ICT. Mandatory conformity assessment scheme (IMAND). In Italy there are several legislation pieces that establish a mandatory conformity assessment scheme for accessibility of ICT, including the definition of requirements, a registry system of accredited third parties registry system and an assessment methodology.

8. ICT hardware. Assessment by privately-recognized third party (IPTHRD). There are few conformity assessment schemes that apply outside the web domain. The most recognized is the TCO label, from Sweden, that includes some accessibility aspects in their quality mark.

9. ICT. First party attestation (IFIRST). In the USA there exists the Voluntary Product Accessibility Template (VPAT), which was developed by US industry and government to show conformance to Section 508. It is a document generated by the supplier (or manufacturer) to disclose to what extent the product addresses requirements. Therefore, a VPAT does not provide a clear yes/no answer for each requirement and for product accessibility.

As a conclusion to the analysis of this group of conformity assessment schemes, it has to be noted that most of them deal with web content and thus use a de facto standard 
(the Web Content Accessibility Guidelines - WCAG) as requirements for the conformity assessment, or national legislation that adapts the content of the WCAG.

\subsection{Conformity Assessment Systems and Schemes in Other Domains}

The third group includes conformity assessment systems or schemes existing in other domains that could be applied to the context of public procurement of accessible ICT products. The examples are of very different types and characteristics, and they are grouped here only because they do not apply to the ICT domain. The full report describes the following: CE marking, Cencer, Common criteria and Keymark.

Table 3. Product-dependent criteria

\begin{tabular}{|c|c|}
\hline Criteria & Description \\
\hline Type of product & $\begin{array}{l}\text { The type of product, as defined in EN ISO } 9000 \text {, combined with the applica- } \\
\text { ble CPV codes (Common Procurement Vocabulary [8], amended by [9]). }\end{array}$ \\
\hline State of technology & $\begin{array}{l}\text { Describes the state of the product's technology on the market. It may be an } \\
\text { existing technology, an existing technology applied to a new domain or a } \\
\text { completely new technology. }\end{array}$ \\
\hline Time to market & $\begin{array}{l}\text { The time that a new product is under development before it reaches the } \\
\text { market. }\end{array}$ \\
\hline Life span & $\begin{array}{l}\text { The time that a product remains on the market before being replaced. Several } \\
\text { things may affect life span: legislation, security, user requirements, etc. }\end{array}$ \\
\hline Rate of changes & How often the product can change (e.g. new features be added) during its use. \\
\hline Adaptability & $\begin{array}{l}\text { Whether the product can be adapted to better suit the needs of its users. Adap- } \\
\text { tations can be easy (like user preferences) or hard (like major changes to user } \\
\text { interface behavior) to make }\end{array}$ \\
\hline $\begin{array}{l}\text { Interoperability with } \\
\text { assistive technologies }\end{array}$ & Whether the product can be connected to assistive technologies \\
\hline Total cost of ownership & $\begin{array}{l}\text { The addition of product-related direct and indirect costs. Not only does it } \\
\text { reflect the cost of purchase but also aspects in the further use and maintenance } \\
\text { of the equipment, device, or system considered }\end{array}$ \\
\hline
\end{tabular}

Table 4. Market-dependent criteria

\begin{tabular}{|l|l|}
\hline Criteria & Description \\
\hline Competition & The degree of product market competitiveness \\
\hline Market awareness & $\begin{array}{l}\text { Level of awareness of accessibility issues among companies, customers and } \\
\text { users }\end{array}$ \\
\hline Market surveillance & $\begin{array}{l}\text { Existence of product conformity assessment after the product goes to the } \\
\text { market. This criterion also covers who is responsible for the market } \\
\text { surveillance. }\end{array}$ \\
\hline $\begin{array}{l}\text { Competitor's surveil- } \\
\text { lance }\end{array}$ & Existence of conformity surveillance performed by the competitors. \\
\hline Barriers to trade & $\begin{array}{l}\text { Whether the assessment of accessibility could generate barriers to trade by } \\
\text { promoting local suppliers }\end{array}$ \\
\hline $\begin{array}{l}\text { Independent expertise } \\
\text { on accessibility }\end{array}$ & $\begin{array}{l}\text { Whether there is expertise on product accessibility and accessibility } \\
\text { conformity assessment. This expertise has to be independent of suppliers } \\
\text { and manufacturers for accessibility requirements to be defined for public } \\
\text { procurement. }\end{array}$ \\
\hline $\begin{array}{l}\text { Size of product suppli- } \\
\text { ers }\end{array}$ & $\begin{array}{l}\text { The type of enterprises dominating the marketplace by size. SMEs and big } \\
\text { worldwide companies do not all have the same resources for conducting } \\
\text { conformity assessments. Remember that at least 95 per cent of the enter- } \\
\text { prises in the EU are SMEs. }\end{array}$ \\
\hline
\end{tabular}


As in the first group, the elements of this third group are generic and most of the dimensions don't have an assigned value. Details are provided in the full report [2].

\section{The Criteria}

The context of a public procurement process can be divided into several elements: (a) the product to be procured; (b) the market the product belongs to; (c) the public administration procuring the product (i.e. the contracting authority); (d) the users that will be using the product; and (e) the public procurement characteristics. We have identified criteria for each of these elements, summarized below in tables 3 to 7 .

Table 5. Public administration-dependent criteria

\begin{tabular}{|l|l|}
\hline Criteria & Description \\
\hline Public task & $\begin{array}{l}\text { The tasks of the public administration. They can be driven by policy, execu- } \\
\text { tion or control. }\end{array}$ \\
\hline Geographical focus & $\begin{array}{l}\text { The geographical level of competence of the contracting authority: local, re- } \\
\text { gional, Member State or European. }\end{array}$ \\
\hline $\begin{array}{l}\text { In-house expertise on } \\
\text { accessibility }\end{array}$ & $\begin{array}{l}\text { Whether the contracting authority has expertise for evaluating suppliers' ac- } \\
\text { cessibility claims in-house. }\end{array}$ \\
\hline Legal requirements & $\begin{array}{l}\text { Whether the public administration has to comply with accessibility-related } \\
\text { legal requirements }\end{array}$ \\
\hline
\end{tabular}

Table 6. User-dependent criteria

\begin{tabular}{|l|l|}
\hline Criteria & Description \\
\hline Risk of harm & $\begin{array}{l}\text { Level of potential risk of producing adverse effects on users. In this report the } \\
\text { 'risk-of-harm' criteria is related only to accessibility-based adverse effects, and } \\
\text { not to safety regulations }\end{array}$ \\
\hline Risk of social exclusion & $\begin{array}{l}\text { The risk of a non-accessible ICT product producing social exclusion of users } \\
\text { with disabilities, because there are no alternatives }\end{array}$ \\
\hline Confidence & The users' level of confidence in accessibility attestations \\
\hline
\end{tabular}

Table 7. Public procurement characteristics-dependent criteria

\begin{tabular}{|l|l|}
\hline Criteria & Description \\
\hline Type of procurement & $\begin{array}{l}\text { According to Hommen's matrix [10]: direct procurement (based on needs } \\
\text { intrinsic to the procuring organization, e.g. e-government services), coopera- } \\
\text { tive procurement (based on shared needs, congeneric to multiple users, e.g. } \\
\text { energy efficient lighting or buildings), catalytic procurement (based on needs } \\
\text { extrinsic to the procuring organization, i.e. needs of other users, e.g. new sus- } \\
\text { tainable technologies). }\end{array}$ \\
\hline Type of procedure & $\begin{array}{l}\text { The type of public procurement process, from direct purchase to fully fledged } \\
\text { procurement. }\end{array}$ \\
\hline Electronic procurement & $\begin{array}{l}\text { Whether or not the procurement is electronic. Electronic procurements have } \\
\text { specific characteristics and should be analyzed separately. There are elec- } \\
\text { tronic procurements both below and above the threshold amount. }\end{array}$ \\
\hline $\begin{array}{l}\text { Prior existence of the } \\
\text { product }\end{array}$ & $\begin{array}{l}\text { Whether the product to be procured exists on the market or has to be devel- } \\
\text { oped. }\end{array}$ \\
\hline Number of units & $\begin{array}{l}\text { The number of product units (or licenses) to be procured. This information is } \\
\text { part of the needs analysis performed in preparation for public procurement. }\end{array}$ \\
\hline Budget & The amount of money that the procurer is expecting to invest. \\
\hline $\begin{array}{l}\text { Liability and account- } \\
\text { ability }\end{array}$ & $\begin{array}{l}\text { Whether the supplier is liable for not providing an accessible product (risk } \\
\text { mitigation procedure...). }\end{array}$ \\
\hline
\end{tabular}




\section{The Scenarios}

The intention of the scenarios is to apply the analysis model of the procurement contexts (the criteria). These scenarios detail the influence of the criteria of the public procurement contexts on the dimensions of conformity assessment systems. The scenarios are hypothetical and merely illustrative. The intention is to show how the criteria are used within the decision-making process and the type of possibilities they output concerning the best conformity scheme to adopt. This reasoning is only illustrative and was not subjected to formal evaluation.

Notice also that tenderers have the option of using another method of proof as long as they can demonstrate that it produces equivalent results. So, even though the scenarios recommend conformity assessment systems or schemes, the public procurer should accept alternative means of proof.

The scenarios were selected to cover four different procurement cases, which are fully described in the report [2]. Here only the potential conformity assessment system or scheme is listed:

- A set of units of desktop laser printers, which is a procurement of off-the-shelf products. Potential system: supplier's declaration of conformity, plus third party determination made by external laboratories.

- A frame contract for mobile communication, including a set of units of mobile phones, which is a procurement of a service including off-the-shelf products. Potential system: supplier's declaration of conformity.

- Development of a web site, which is a common procurement case. Potential system: product inspection according to ISO/IEC 17020.

- A road traffic management system, which is a complex object of procurement. Potential system: certification (for individual components) and self declaration of conformity (for the full system).

\section{Conclusions and Further Work}

The CEN/CENELEC report [2] has presented an analysis of conformity assessment systems and schemes that could be applied in the domain of the public procurement of accessible ICT products and services. Some conclusions can be drawn.

First the procurement of ICT is a highly complex process with many variables. Due to this complexity and diversity one conformity assessment system (and less so a scheme) is unlikely to be applicable across all the situations covered by the public procurement of accessible ICT.

A second key concept is that the European Public Procurement Directives give the contracting authority limited freedom of choice as to require what means the suppliers can use to demonstrate the accessibility of the offered products: the contracting authority has to accept equivalent means of proof of conformity.

A third extremely important concept is that assessment of conformity to specified requirements is a fundamental element of the evaluation of tenders. The contracting authority has to be able to analyze the different tenders and rank them with respect to conformity to the accessibility requirements. 


\section{References}

1. European Commission. M/376. Standardisation Mandate to CEN. CENELEC and ETSI in support of European accessibility requirements for public procurement of products and services in the ICT domain (December 2005)

2. CEN/BT WG 185 Project Team Final Report for Approval. European accessibility requirements for public procurement of products and services in the ICT domain (European Commission Mandate M 376, Phase 1) (September 2008),

ht tp: / /econformance.eu/

3. ETSI DTR 102612 V 50. Human Factors (HF); European accessibility requirements for public procurement of products and services in the ICT domain (European Commission Mandate M 376, Phase 1). Final draft for ESO TB cross-approval (September 2008). http://portal.etsi.org/stfs/STF_HomePages/STF333/STF333.asp

4. IDC White Paper Using Appropriate Conformity Assessment Tools to Ensure Effective Consumer Protections (2007), http: / /ww . itic.org/archives/articles/2007b/ IDC_White_Paper_on_Conformance_Assessment_Nov2007.pdf

5. EN ISO/IEC 17000:2004 Conformity assessment - Vocabulary and general principles (2004)

6. Directive 2004/18/EC of the European Parliament and of the Council of 31 March 2004 on the coordination of procedures for the award of public works contracts, public supply contracts and public service contracts (2004),

http: / /eur-lex.europa.eu/LexUriserv/LexUriserv.do?uri= CELEX: 32004 L0018: EN: NOT

7. WAB Cluster. Unified Web Evaluation Methodology version 1.2 (2007), http: / / www. wabcluster.org/uwem1_2/

8. Regulation (EC) No 2195/2002 of the European Parliament and of the Council of 5 November 2002 on the Common Procurement Vocabulary (CPV) [Official Journal L 340 of $16.12 .2002]$

9. Commission Regulation (EC) No 2151/2003 of 16 December 2003 [Official Journal L 329 of 17.12.2003]

10. Hommen, L., Rolfstam. M.: Public Procurement and Innovation: Towards a Taxonomy. Journal of Public Procurement 9(1), 17-56 (2009) 